\title{
Defining the Migrating Population of Sinking States from the Perspective of International Law
}

\author{
Anastasia VASILYEVA \\ Department of Public International Law \\ Peoples' Friendship University of Russia (RUDN \\ University) \\ Moscow, Russia
}

\author{
Ekaterina V. KISELEVA* \\ Department of Public International Law \\ Peoples' Friendship University of Russia (RUDN \\ University) \\ Moscow, Russia \\ kiseleva_ev@gmail.com
}

\begin{abstract}
Owing to the absence of universally agreed approaches to migration, which is related to environmental changes and/or natural disasters, the case of sinking states population changes of residence is taken to illustrate nuances in terminology that reflect the substantial differences in legal treatment of such persons. This paper presents the existing variations of denoting the link between migration and environmental changes of sinking states with the special focus on the shades of meaning of the terminology in use and then suggests to give separate attention to the forced or voluntary character of such migration and its expression in terms.
\end{abstract}

Keywords_International law; Migration; Sinking states

\section{INTRODUCTION}

Migration caused by natural reasons is known for thousands of years. Nowadays, when the inter-state cooperation tends to be formalized and institutionalized as never before, such migration poses a lot of questions from the legal prospective. What is the status of individuals whose decision to change their place of residence is dictated by negative environmental processes and natural disasters? What are the obligations of states in respect of endangered states and their population, if any obligation exists at all? One of the most illustrative and complex situations in this context is connected with the disappearing states, here, those who lose their territories due to the rise of the sea-level and whose population is forced to resettle or choose to do so due to submergence of state territories (Tuvalu, Kiribati, the Marshall Islands, etc.). The present paper is the attempt of conceptualization of the terminology used in respect of the population of the sinking states, as the terminology reflects the nuances in qualification of the respective cases.

\section{DEFINING A CORRECT LINK BETWEEN MIGRATION AND ENVIRONMENTAL CHANGES OF SINKING STATES}

At present, in international law there is no universally accepted definition denoting persons moving as a result of the adverse effects of climate change, one of which is the submergence of state territory. Moreover, general understanding of the scope of the broader concept of 'environmental migration' is currently missing [1]. To refer to persons displaced for environmental reasons, there are various doctrinal definitions that usually include those moving as a result of the adverse effects of climate change, e.g. [1-2]:

- environmental refugee / environmentally displaced person $(E D P)$;

- environmental migrant,

- forced environmental migrant;

- environmentally motivated migrant;

- climate change migrant/refugee/displaced person;

- persons forced to leave their territory of residence due to environmental reasons;

- eco-migrant/refugee.

The position of D.K. Bekyashev and D.V. Ivanov is of great importance in respect of categorizing the persons under consideration. The two scientists singled out the category of persons displaced by the adverse effects of climate change, from a wider category of environmental migrants. In the opinion of these lawyers, "the most appropriate term for persons who migrate for reasons of environmental change is "persons displaced for environmental reasons" [3, p. 46]. However, they believe that the term 'climate migrant' is narrower than the term 'environmental migrant', because climate change, leading to the deterioration in the quality of life of the population, is only one of the causes of environmental migration. Accordingly, the word 'climate' is more appropriate for the specifics of the sinking states, and can more accurately denote the population of the disappearing states.

It is also important to notice that D.K. Bekyashev and D.V. Ivanov speak about subgrouping of climate migrants depending on the type of adverse effects of climate change, such as hydrometeorological disasters; progressive emergencies (such as reduction of water supplies, etc.); armed conflicts in the struggle for limited and diminishing natural resources; environmental degradation; significant permanent loss of state territory as a result of rising sea level [3, p. 52]. Such accuracy in categorizing groups of climate migrants that undoubtedly represents a significant contribution to the development of international law science, does not allow us to 
use the broader term 'climate migrant' for the persons under consideration in the present study. It is obvious that the population of sinking states fall in this classification under the category of persons displaced due to a significant permanent loss of the state territory as a result of rising sea level. However, the submergence of whole islands can be accompanied by natural disasters (typhoons, tsunamis, floods, earthquakes, etc.). That was also confirmed at the universal level in the 2016 New York Declaration for Refugees and Migrants adopted at the high-level plenary meeting of the United Nations General Assembly (hereinafter UNGA) on addressing large movements of refugees and migrants (the UN Summit for Refugees and Migrants), held on September 19, 2016, in New York [4]. So, the people under consideration may well fall under the first two categories in the above presented classification. Therefore, such narrower categories will not necessarily correspond to the facts, and shall be substituted with a broader notion.

At the same time, the term 'climate migrant' as a broader category does not clearly reflect reality either, since, firstly, climate change is not a direct cause of population migration, rather, migration is a direct consequence of the adverse effects caused by climate change (in this the case of submerging the state territory and, hypothetically, natural disasters and catastrophes), that is, there is a causal chain of interrelations of these phenomena. Secondly, this general term does not disclose the nature of such migration, i.e. whether it is forced or voluntary [5].

It is interesting that, if we trace the terminology used for such persons in the documents of the Conferences of the Parties to the UN Framework Convention on Climate Change and the meetings of the Parties to the Kyoto Protocol, we can see how it changed [6]. In the framework of the Conference of the Parties in Poznan in 2008 it was about 'migration and displacement'; in 2009, in the document adopted after the seven sessions of the Ad Hoc Working Group on Long-term Cooperative Measures, the term 'climate refugees' was used; within the framework of the 15th Conference UN Climate Change and the 5th Meeting of the Parties to the Kyoto Protocol there was 'human mobility'; in the agreements adopted at the end of the 16th UN Conference on Climate Change and the 6th Meeting of the Parties to the Kyoto Protocol 2010 'migration and planned relocations' (para. 14 (e)) is used; the 2015 Paris Climate Change Agreement incorporates the wording 'population movement associated with the negative effects of climate change'.

The most relevant documents adopted at the UN Summit for Refugees and Migrants, held on September 19, 2016, in New York, use a general term that combines the causes of environmental movements outlined above, i.e. "persons crossing international borders due to natural disasters and the adverse effects of climate change' [4]. As the UNGA noted in its declaration, some of the disasters may be related to climate change, and some may not. In the situation under consideration, such a reason for displacement as submerging of the state territory does not cause doubts, however such a reason for displacement as a natural disaster or catastrophe is ambiguous, since the probability that such disasters and catastrophes occur and at the same time cause population movements of endangered states is not absolute. It can happen, for example, in one of the endangered states [4], and it does not happen in the others, or it may not happen at all.

Taking into account these circumstances, as well as using the relevant developments of the international law doctrine, in this study we prefer the term 'persons displaced by the adverse effects of climate change' to denote the whole resettling population of disappearing states, whether the movement is a result of a gradual submergence of the state territory or whether such deterioration of the environmental situation is accompanied by natural disasters or a disaster. For the analysis of the legal status of the population of endangered states in the event of a hypothetical environmental disaster or catastrophe, we will use the term 'persons displaced by the adverse effects of climate change', and the term 'persons voluntarily migrating as a result of the adverse effects of climate change' for the analysis of the voluntary gradual migration.

\section{THE CHARACTER OF MIGRATION OF OF SINKING STATES POPULATION: FORCED OF VOLUNTARY}

D.K. Bekyashev and D.V. Ivanov point out that the general notion of an 'environmental migrant' covers persons moving "both within and beyond state borders, both as a result of extreme environmental circumstances, and those of them whose displacement is caused by a gradual deterioration in the quality of the environment" [3, p. 52], both short-term and long-term (or permanent) migrants, both forced and voluntary migrants. Considering that the group of persons under consideration is a narrower category in the given context, it is necessary to determine the applicability of these dichotomies to persons displaced as a result of the adverse effects of climate change.

Given the gradual nature of the submergence of the state territory, it is predictable that, at the initial stage at least, the population will move to the elevated areas of their states, that is, the migration at first may be of an intrastate nature [7]. This statement is especially true, if the states manage to reconstruct their own territory so that it remains above the sea level and suitable for living. However, if the reconstruction plans fail, or proves to be impossible, given the threat of complete submergence of the territory or its transformation into uninhabitable, such migration will have an international character.

Despite the fact that many authors define environmental migration generally as forced $[8,9 ; s f .10]$, it is necessary to distinguish between forced and voluntary migrants displaced due to the adverse effects of climate change. The number of scientists dividing them is growing $[11,12,13,14]$. V.I. Yevtushenko notes, "Migrants moving due to environmental and technological disasters (typhoons, floods, tsunamis, earthquakes, explosions, fires, radiation, chemical, bacteriological accidents, etc.) should be distinguished from migrants moving as a result of the gradually worsening environmental situation as a result of climate change" $[11,12]$, the latter should be qualified as voluntary migrants.

It is obvious that global warming, as a result of which the level of the World Ocean rises, occurs gradually, unlike 
natural disasters such as tsunamis, earthquakes, floods, fires, etc. Accordingly, the phenomenon itself is gradual and irreversible, it is about forecasts for a century ahead, and not about an emergency. So, according to J. McAdam, it is unlikely that the population will be evacuated at a moment, rather its resettlement will be gradual and, most likely, quite random, i.e. having several states as destinations [15]. This circumstance raises a question of whether leaving a country is the only way out for the population of disappearing states [10]. The state territory of the disappearing states is submerging insensibly. The governments of such states have an opportunity to plan in advance measures to save their people (the people can influence the state, and it, in turn, can raise the issue at the international level and ask the international community for assistance). Moreover, there are theoretical and practical developments in building up the territory through its reconstruction with the help of bedded rockfills, dams, etc. The existence of these arguments weakens the position recognizing the migration of the population of the disappearing states as forced. Such a planned migration can be considered as voluntary.

However, there is a position that the submerging of the state territory can be accompanied by natural disasters, e.g. tsunamis, typhoons, earthquakes, floods, etc. For example, the 2016 New York Declaration, adopted at the UN Summit for Refugees and Migrants, held on September 19, 2016, in New York, also applies to "people displaced to avoid adverse climate change or natural disasters (some of which may be related to climate change) or due to other environmental factors" [4]. Indeed, the disappearing states (Tuvalu, Kiribati, Marshall Islands, etc.) have already suffered from significant natural disasters [16]. Accordingly, such a migration may have a dual character. Thus, the International Organization for Migration divides migration for environmental reasons into voluntary and forced, but notes that there is also a "gray zone", including "difficult situations that may include elements of both types of migration" [3, p. 51].

\section{CONCLUSION}

The question of whether this migration is recognized as forced or voluntary is important for people displaced as a result of the adverse effects of climate change, since, in case of forced migration, such persons "can receive full protection if, for example, they meet the criteria of refugees" $\lceil 3$, p. 53], or may be granted another protection status used for forced migrants. In other words, "the determination of the degree of voluntariness makes it possible to determine whether such a migrant can apply for a refugee status, if there are additional reasons for migration, allowing to qualify him/her as a refugee" [3, p.54]. It can, thus, be assumed, at least theoretically, that forced migrants can be entitled to a refugee status, but for voluntary migrants it is not feasible at all. A number of authors are in favour of calling such persons displaced in connection with environmental disasters and catastrophes as 'environmental refugees' [17-18], however it is very disputable.

Thus, the answer to the questions what is the legal status of the persons displaced as a result of the adverse effects of climate change and what existing principles and norms of international law (for example, prohibition of expulsion, etc.) may be applicable to persons displaced by the adverse effects of climate change, if migration is forced, determines the correct terminology in respect of the population of sinking states.

\section{ACKNOWLEDGMENT}

This research was financially supported by the Russian Foundation for Humanities, project No. 16-03-50188.

\section{REFERENCES}

[1] D.J. Bulesheva, "Environmental Migration: Essence, Problems and Possible Solutions," Human Resource Management, vol. 15, p. 23, 2007. (In Russian)

[2] D.V. Ivanov, D.K. Bekyashev, Environmental Migration in International Law. Cambridge: Cambridge Scholars Publishing, 2016.

[3] D.V. Ivanov, D.K. Bekyashev, Environmental migration of population International legal aspects. Moscow: Aspect-press, 2013. (In Russian)

[4] New York Declaration for Refugees and Migrants. UN Doc. $\mathrm{A} / \mathrm{RES} / 71 / 1$. Information http://www.un.org/en/ga/search/view doc.asp?symbol=A/RES/71/1.

[5] D.V. Ivanov, D.K. Bekyashev, International legal regulation of forced and labor migration. Moscow: Prospekt, 2015. (In Russian)

[6] S.D. Belockiy, "International legal mechanisms of responsibility for the harm to climate leading to change of the state territory formation," The Legal Initiative, vol. 3, 2014. Information on http://49e.ru/en/2014/3/15 (full text in Russian, abstract in English)

[7] Tuvalu: Climate Change and Migration: Relationships Between Household Vulnerability, Human Mobility and Climate Change. Information on https://tinyurl.com/ydgybyod.

[8] D.J. Bulesheva, "Environmental migration today: Problems and possible solutions," Human resource management, vol. 15, pp. 49-51, 2007. (In Russian)

[9] A.P. Anisimov, Z.V. Dodgaeva, "The legal status of environmental refugees in international law," Agrarian and land law, vol. 10 (118), pp. 67-83, 2014. (In Russian)

[10] K.M. Wyman, "Sinking States," in: D.H. Cole and E. Ostrom, Eds., Property in Land and Other Resources. Cambridge: Lincoln Institute of Land Policy, 2012, pp. 439-369.

[11] V.I. Evtushenko, "Classification of environmental migration," Actual problems of Russian law, vol. 2, pp. 145-150, 2009. (In Russian)

[12] V.I. Evtushenko, "Environmental migration: concept, types, place in the domestic legal system," Migration Law, vol. 2, pp. 13-17, 2010. (In Russian)

[13] J. Money, T.W. Taylor, Voluntary International Migration. Information on https://tinyurl.com/y7q9rj12

[14] F. Biermann, I. Boas, "Preparing for a Warmer World: Towards a Global Governance System to Protect Climate Refugees," Global Environmental Politics, pp. 60-88, 2010.

[15] J. McAdam, Climate Change, Forced Migration, and International Law. Oxford: Oxford University Press, 2012.

[16] Cyclone Pam left widespread damage in the Solomon Islands, Kiribati, Tuvalu and New Caledonia. Information on https://www.iom.int/news/iom-joins-response-cyclone-pam-devastationvanuatu.

[17] D.C. Bates, "Environmental Refugees? Classifying Human Migrations Caused by Environmental Change," Population and Environment, vol. 23(5), pp. $465-477,2002$.

N. Myers, "Environmental Refugees: A Growing Phenomenon of the 21st Century," Philosophical Transactions of the Royal Society B: Biological Sciences, pp. 609-613, 2002. 